ARTICLE

\title{
The underappreciated role of agricultural soil nitrogen oxide emissions in ozone pollution regulation in North China
}

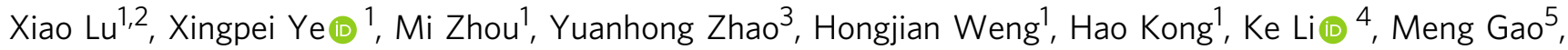
Bo Zheng (i) ${ }^{6}$, Jintai Lin (10 ${ }^{1}$, Feng Zhou (1) ${ }^{7}$, Qiang Zhang ${ }^{8}{ }^{8}$, Dianming Wu (i) ${ }^{9}$, Lin Zhang (1) ${ }^{1 凶} \&$ Yuanhang Zhang ${ }^{10 凶}$

Intensive agricultural activities in the North China Plain (NCP) lead to substantial emissions of nitrogen oxides $\left(\mathrm{NO}_{\mathrm{x}}\right)$ from soil, while the role of this source on local severe ozone pollution is unknown. Here we use a mechanistic parameterization of soil $\mathrm{NO}_{x}$ emissions combined with two atmospheric chemistry models to investigate the issue. We find that the presence of soil $\mathrm{NO}_{x}$ emissions in the NCP significantly reduces the sensitivity of ozone to anthropogenic emissions. The maximum ozone air quality improvements in July 2017, as can be achieved by controlling all domestic anthropogenic emissions of air pollutants, decrease by $30 \%$ due to the presence of soil $\mathrm{NO}_{x}$. This effect causes an emission control penalty such that large additional emission reductions are required to achieve ozone regulation targets. As $\mathrm{NO}_{x}$ emissions from fuel combustion are being controlled, the soil emission penalty would become increasingly prominent and shall be considered in emission control strategies.

\footnotetext{
${ }^{1}$ Laboratory for Climate and Ocean-Atmosphere Studies, Department of Atmospheric and Oceanic Sciences, School of Physics, Peking University, Beijing, China. ${ }^{2}$ School of Atmospheric Sciences, Sun Yat-sen University, Zhuhai, Guangdong, China. ${ }^{3}$ College of Oceanic and Atmospheric Sciences, Ocean University of China, Qingdao, China. ${ }^{4}$ John A. Paulson School of Engineering and Applied Sciences, Harvard University, Cambridge, MA, USA. ${ }^{5}$ Department of Geography, Hong Kong Baptist University, Hong Kong, China. ${ }^{6}$ Laboratoire des Sciences du Climat et de I'Environnement, CEA-CNRS-UVSQ, Gif-sur-Yvette, France. ${ }^{7}$ Laboratory for Earth Surface Processes, College of Urban and Environmental Sciences, Peking University, Beijing, China. ${ }^{8}$ Ministry of Education Key Laboratory for Earth System Modeling, Department of Earth System Science, Tsinghua University, Beijing, China. ${ }^{9}$ Key Laboratory of Geographic Information Sciences, School of Geographic Sciences, East China Normal University, Shanghai, China. ${ }^{10}$ State Key Joint Laboratory of Environmental Simulation and Pollution Control, College of Environmental Sciences and Engineering, Peking University, Beijing, China. ${ }^{凶}$ email: zhanglg@pku.edu.cn; yhzhang@pku.edu.cn
} 
S urface ozone is a major air pollutant that is harmful to human health and vegetation ${ }^{1-3}$. Extensive surface ozone measurements from global monitoring networks have revealed that summertime ozone levels, and the associated health exposures over the North China Plain (NCP) are significantly higher than those over other northern mid-latitude regions ${ }^{4,5}$. Despite the fact that the Chinese Action Plan on Air Pollution Prevention and Control implemented in 2013 has significantly reduced the nationwide anthropogenic emissions of primary pollutants including particulate matter $(\mathrm{PM})$ and nitrogen oxides $\left(\mathrm{NO}_{\mathrm{x}}=\mathrm{NO}+\mathrm{NO}_{2}\right)^{6,7}$, summertime ozone pollution, measured as daily $8 \mathrm{~h}$ average maximum (MDA8) has been increasing at over 3 ppbv year $^{-1}$ in the NCP over 2013-2019, among the fastest urban ozone trends in the recent decade reported in the Tropospheric Ozone Assessment Report $(\mathrm{TOAR})^{8-10}$. Recent studies suggested that the ozone increases were likely driven by decreases of PM and anthropogenic $\mathrm{NO}_{\mathrm{x}}$, and changes in meteorological conditions ${ }^{11-15}$. The observed ozone increases during the coronavirus disease 2019 (COVID-19) lockdown in China also reflected the complexity of ozone mitigation ${ }^{16-18}$. Here we show that the substantial soil $\mathrm{NO}_{\mathrm{x}}$ emissions present an additional challenge for ozone pollution regulation in the NCP.

Surface ozone is primarily produced from the sunlight-driven oxidation of volatile organic compounds (VOCs) and carbon monoxide $(\mathrm{CO})$ in the presence of $\mathrm{NO}_{\mathrm{x}}$. These precursors are emitted from both anthropogenic (fuel combustion from power plants, industry, transportation, and residential sources) and biogenic sources (e.g., $\mathrm{NO}_{\mathrm{x}}$ from soil). Being the most intensive anthropogenic emission regions in China ${ }^{19}$, the NCP also contains $23 \%$ of Chinese cropland areas (agricultural areas of about $300,000 \mathrm{~km}^{2}$ ) and uses $30 \%$ of the national fertilizer consumption $^{20}$. The intensive nitrogen inputs to soil from fertilizer applications ${ }^{21}$ and nitrogen deposition ${ }^{22}$ lead to large soil $\mathrm{NO}_{\mathrm{x}}$ emissions via microbial processes reaching $20 \%$ of the anthropogenic $\mathrm{NO}_{\mathrm{x}}$ emissions in summer over the $\mathrm{NCP}^{13,23,24}$. The soil $\mathrm{NO}_{\mathrm{x}}$ emissions from both the natural nitrogen pool and fertilizer input are conventionally considered as biogenic sources, and are not considered in the current design of emission control strategies in China ${ }^{7,25}$.

The contribution of soil $\mathrm{NO}_{\mathrm{x}}$ emissions to ozone formation in the NCP is complicated by the nonlinear ozone chemistry in the presence of high anthropogenic sources. The efficiency of ozone formation largely depends on the photochemical regime, i.e., whether it is sensitive to $\mathrm{NO}_{\mathrm{x}}\left(\mathrm{NO}_{\mathrm{x}}\right.$-limited regime) or VOCs $\left(\mathrm{NO}_{\mathrm{x}}\right.$-saturated regime) or both (transitional regime). Observational and modelling studies have shown that ozone formation in the NCP is typically in transitional or $\mathrm{NO}_{\mathrm{x}}$-saturated regime in urban and suburban areas, and in $\mathrm{NO}_{\mathrm{x}}$-limited regime for rural areas $^{11,26-29}$. Significant ozone enhancements from agricultural soil $\mathrm{NO}_{\mathrm{x}}$ emissions in $\mathrm{NO}_{\mathrm{x}}$-limited regions were suggested in some recent studies ${ }^{30-33}$, yet no studies so far have examined how soil $\mathrm{NO}_{\mathrm{x}}$ emissions interact with anthropogenic sources in $\mathrm{NO}_{\mathrm{x}}{ }^{-}$ rich regions such as the NCP. Soil $\mathrm{NO}_{\mathrm{x}}$ emissions are typically simplified or neglected in many air quality models applied for ozone source attributions and emission control strategy assessments in China ${ }^{15,34,35}$, and the implication of this missing source is still unknown.

In this work, we address the issue by applying two atmospheric chemistry model simulations (GEOS-Chem and WRF-Chem) under different anthropogenic and soil emission scenarios. Soil $\mathrm{NO}_{\mathrm{x}}$ emissions are estimated by a mechanistic parameterization and can be supported by field measurements and satellite observations of tropospheric $\mathrm{NO}_{2}$ columns. We demonstrate that the presence of soil $\mathrm{NO}_{\mathrm{x}}$ emissions in the NCP that largely driven by fertilizer application, significantly reduces the sensitivity of surface ozone to anthropogenic $\mathrm{NO}_{\mathrm{x}}$ emissions, degrades the effectiveness of anthropogenic emissions control measures on surface ozone regulation, and therefore serves as a penalty requiring extra anthropogenic emission reduction. This study highlights the previously underappreciated important role of soil $\mathrm{NO}_{\mathrm{x}}$ emissions on accurate attribution of anthropogenic ozone sources that is crucial for designing ozone pollution regulation strategies.

\section{Results and discussion}

Anthropogenic and soil $\mathrm{NO}_{\mathrm{x}}$ emissions in the NCP. Figure 1 compares the anthropogenic and soil $\mathrm{NO}_{\mathrm{x}}$ emissions over China at $0.25^{\circ} \times 0.3125^{\circ}$ resolution in July 2017 . We choose July here as it is a typical boreal summer month with intensive soil emissions and severe ozone pollution in the $\mathrm{NCP}^{13}$. Anthropogenic $\mathrm{NO}_{\mathrm{x}}$ emissions from the Multi-resolution Emission Inventory for China (MEIC ${ }^{6,19}$; with latest available year 2017) include combustion sources, i.e., industry, transportation, power plant, and residential processes, while agricultural $\mathrm{NO}_{\mathrm{x}}$ emissions are not included. The total combustion induced anthropogenic $\mathrm{NO}_{\mathrm{x}}$ emissions over China in July 2017 are $0.53 \mathrm{Tg} \mathrm{N}$, with $31 \%(0.16$ $\mathrm{Tg} \mathrm{N}$ ) of them emitted in the NCP region. The MEIC inventory estimates that anthropogenic $\mathrm{NO}_{\mathrm{x}}$ emissions in the NCP for July peaked at $0.23 \mathrm{Tg} \mathrm{N}$ in 2011 and has decreased since then due to emission control measures ${ }^{6}$, consistent with trends in satellite observed $\mathrm{NO}_{2}$ tropospheric columns ${ }^{36}$.

Soil $\mathrm{NO}_{\mathrm{x}}$ emissions are calculated using the Berkeley-Dalhousie Soil $\mathrm{NO}_{\mathrm{x}}$ Parameterization (BDSNP) as a function of available soil nitrogen content from fertilizer application and nitrogen deposition, and edaphic conditions such as soil moisture and temperature $^{37,38}$. Its implementation in the GEOS-Chem model driven by assimilated meteorological fields allows the online calculation of hourly soil $\mathrm{NO}_{\mathrm{x}}$ emissions at each model grid (Methods; Supplementary information). The estimated annual total soil $\mathrm{NO}_{\mathrm{x}}$ emissions above canopy in $2008-2017$ are $0.77 \pm$ $0.04 \mathrm{Tg} \mathrm{N}$ per annum $\left(\mathrm{Tg} \mathrm{N} \mathrm{a}^{-1}\right.$ ) (mean \pm standard deviation of annual totals) in China and $0.18 \pm 0.01 \mathrm{Tg} \mathrm{N} \mathrm{a}^{-1}$ in the NCP with small meteorology-driven interannual variability. A distinct seasonal variation exists in the soil $\mathrm{NO}_{\mathrm{x}}$ emissions, with the highest emissions of $0.034 \pm 0.003 \mathrm{Tg} \mathrm{N}$ month $^{-1}$ in May-July 2008-2017 and 0.03 $\mathrm{Tg} \mathrm{N}$ in July 2017 in the NCP (Supplementary Fig. 1). Separating soil $\mathrm{NO}_{\mathrm{x}}$ from natural soil nitrogen content and fertilizer content in the BDSNP parameterization indicates that fertilizer-induced emissions (Methods) are the main component in eastern China, accounting for $58 \%$ of the July soil $\mathrm{NO}_{\mathrm{x}}$ emissions in the NCP (Fig. 1c). Compared with MEIC, the soil $\mathrm{NO}_{\mathrm{x}}$ emissions in the NCP are about $11-20 \%$ of the anthropogenic sources in July 2008-2017, and become higher in more recent years due to the decline of the latter. From a global perspective, the NCP stands out with both high anthropogenic and soil $\mathrm{NO}_{\mathrm{x}}$ emissions, in contrast to other surface ozone hot spots such as the US, Europe, Japan, and Korea recorded in $\operatorname{TOAR}^{9,10}$ where the two sources are typically well separated spatially (Supplementary Fig. 2).

Our estimated soil $\mathrm{NO}_{\mathrm{x}}$ emissions above canopy of $0.77 \pm 0.04$ $\operatorname{Tg~} \mathrm{N} \mathrm{a}^{-1}$ in China are comparable with previous studies in the range of $0.4-1.3 \mathrm{Tg} \mathrm{N} \mathrm{a}^{-1}$, and consistent with independent field measurements across China (Fig. 1d, Supplementary Tables 1 and 2). The NCP is a region with intensive croplands (Supplementary Fig. 1), with high surface $\mathrm{NO}_{\mathrm{x}}$ and $\mathrm{N}_{2} \mathrm{O}$ concentrations being observed in the region after fertilizer applications ${ }^{39-41}$. The presence of soil $\mathrm{NO}_{\mathrm{x}}$ emissions in the $\mathrm{NCP}$ is further evident from satellite observations of tropospheric $\mathrm{NO}_{2}$ column. We compare in Fig. 1e and Supplementary Fig. 3 the GEOS-Chem model simulated tropospheric $\mathrm{NO}_{2}$ columns with or without soil $\mathrm{NO}_{\mathrm{x}}$ emissions to three OMI $\mathrm{NO}_{2}$ satellite products (Methods). Simulated tropospheric $\mathrm{NO}_{2}$ columns in the NCP with soil 


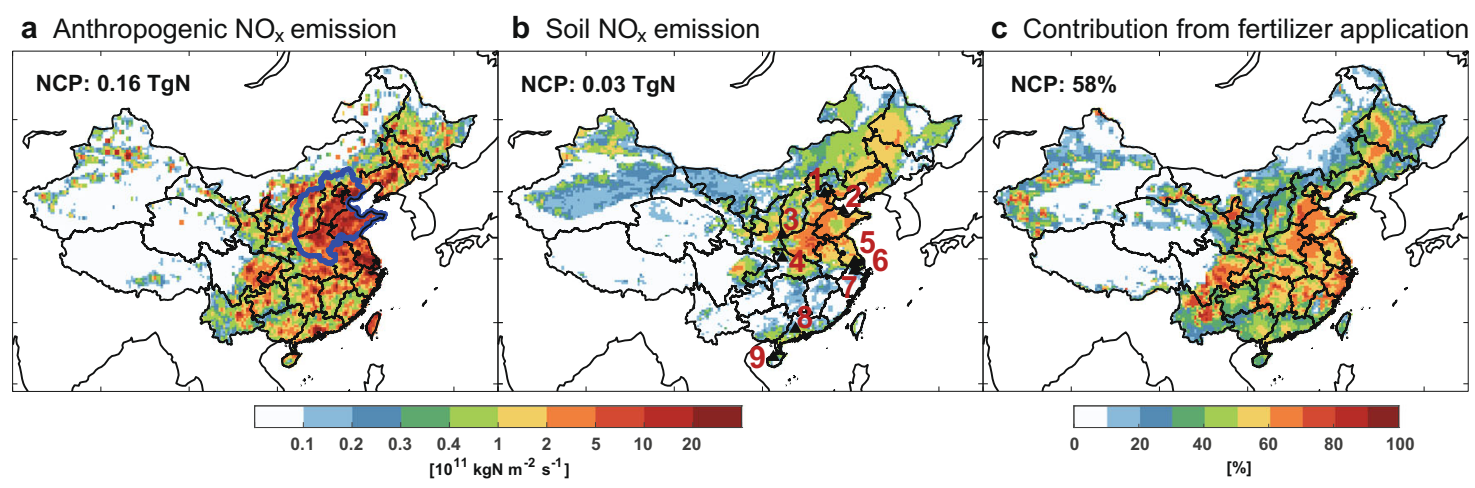

d Comparison to soil $\mathrm{NO}_{\mathrm{x}}$ flux measurements

e Observed and GEOS-Chem tropospheric $\mathrm{NO}_{2}$ column
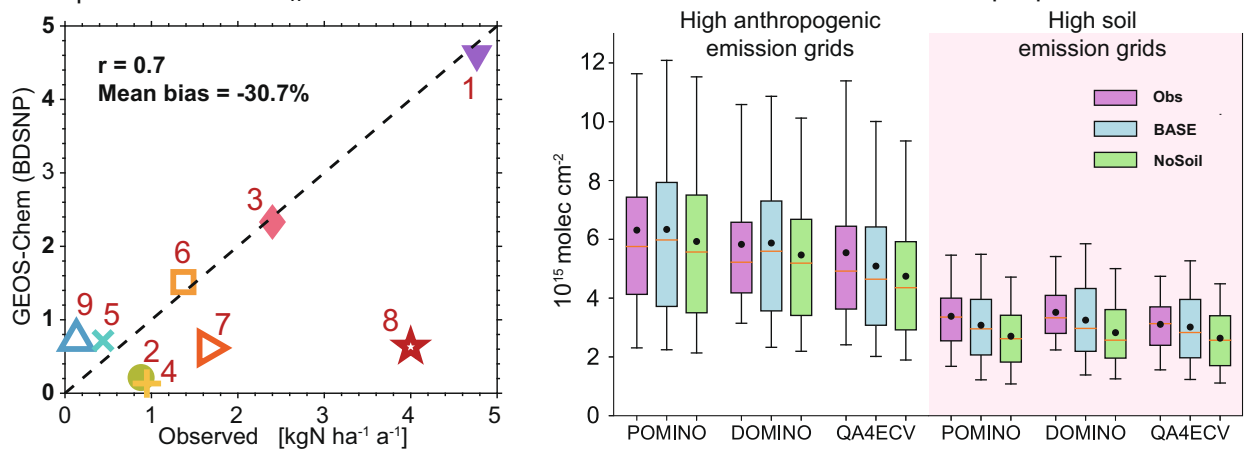

Fig. 1 Substantial anthropogenic and soil $\mathbf{N O}_{x}$ emissions lead to high $\mathbf{N O}_{2}$ levels over the North China Plain (NCP). Panels a and $\mathbf{b}$ show the anthropogenic $\mathrm{NO}_{x}$ emissions in July 2017 from the Multi-resolution Emission Inventory for China (MEIC) and the soil $\mathrm{NO}_{x}$ emissions calculated from the Berkeley-Dalhousie Soil $\mathrm{NO}_{x}$ Parameterization (BDSNP) implemented GEOS-Chem, respectively. The thick blue lines outline the NCP region. The total emissions in the NCP are shown in the inset. Panel $\mathbf{c}$ shows the fraction of soil $\mathrm{NO}_{x}$ emissions from fertilizer application to the total soil $\mathrm{NO}_{x}$ emissions. Panel $\mathbf{d}$ compares the BDSNP soil $\mathrm{NO}_{x}$ emissions to nine field measurements across China (locations given in the Panel $\mathbf{b}$ and Supplementary Table 2, with the correlation coefficient and mean bias shown in the inset. Panel e compares the GEOS-Chem simulated tropospheric $\mathrm{NO}_{2}$ columns over the NCP with averaging kernel applied to the POMINO, DOMINO, and QA4ECV satellite products (Methods). The colored box-and-whisker plots (5th, 25th, 50th, 75th, and 95th percentiles, and mean values denoted as dots) represent $\mathrm{NO}_{2}$ columns from the observation, GEOS-Chem BASE simulation, and a sensitivity model simulation with soil $\mathrm{NO}_{x}$ emissions excluded (NoSoil). The comparisons are grouped for the high anthropogenic $\mathrm{NO}_{x}$ emission model grids (defined as grids with the $20 \%$ anthropogenic/soil $\mathrm{NO}_{x}$ emission ratio greater than 2, accounting for $20 \%$ of the $\mathrm{NCP}$ grids), and high soil $\mathrm{NO}_{x}$ emission model grids (defined as grids with the $20 \%$ anthropogenic/soil $\mathrm{NO}_{x}$ emission ratio smaller than 0.5 , accounting for $30 \%$ of the NCP grids) (Supplementary Fig. $1 \mathrm{c}$ ). We use the emission ratio of $20 \%$ as the criteria here as the July soil $\mathrm{NO}_{\mathrm{x}}$ emissions in the $\mathrm{NCP}$ are about $20 \%$ of the anthropogenic $\mathrm{NO}_{x}$ emissions (a, b). Supplementary Figure 3 compares the spatial distributions.

emissions are consistent with the observations with mean differences less than $5 \%$, but if soil $\mathrm{NO}_{\mathrm{x}}$ emissions are excluded model results would be biased low by $15-20 \%(P<0.01)$ in areas with low anthropogenic/soil emission ratios (Supplementary Fig. 1c), and by $12-14 \%(P<0.01)$ for all the NCP areas.

Impact of soil $\mathrm{NO}_{\mathrm{x}}$ emissions on ozone formation in the NCP. We analyze how soil $\mathrm{NO}_{\mathrm{x}}$ emissions affect ozone formation from anthropogenic sources in the NCP region. Ozone enhancements from a specific source can be determined in atmospheric chemistry models as the differences between the standard simulation with all emissions turned on and a sensitivity simulation with this source turned off or perturbed (Methods; Supplementary Table 3). Here we apply the GEOS-Chem chemical transport model with the MEIC anthropogenic emissions and BDSNP soil $\mathrm{NO}_{\mathrm{x}}$ emissions at $0.25^{\circ} \times 0.3125^{\circ}$ resolution over China (Methods). Our previous work has evaluated the GEOS-Chem ozone simulation for March-October 2016-2017 with the same model configuration using measurements from the nationwide monitoring network of the Chinese Ministry of Ecology and Environment ${ }^{13}$. We show in Fig. 2 and Supplementary Fig. 4 that the model reproduces the spatial pattern of ozone distribution $(r=0.72)$, with a small positive mean bias of $2 \mathrm{ppbv}$ for MDA8 ozone measured at the NCP cities in July 2017.
Substantial differences are found in anthropogenic ozone enhancements simulated by turning off domestic anthropogenic sources in the presence vs. absence of soil $\mathrm{NO}_{\mathrm{x}}$ emissions (Fig. $2 \mathrm{c}$ and d). Monthly mean anthropogenic ozone enhancements in July average $21.2 \mathrm{ppbv}$ in the NCP when soil $\mathrm{NO}_{\mathrm{x}}$ emissions are considered (16.6-24.8 ppbv with a factor of 2 uncertainty in soil $\mathrm{NO}_{\mathrm{x}}$ emissions, i.e., by applying $200 \%$ or $50 \%$ of the BDSNPestimated Chinese soil $\mathrm{NO}_{\mathrm{x}}$ emissions in the model as informed by Supplementary Table 1), which is $30 \%$ (19-46\%) lower than the value of $30.7 \mathrm{ppbv}$ if soil $\mathrm{NO}_{\mathrm{x}}$ emissions are removed in GEOS-Chem model simulations. These anthropogenic ozone values estimate the largest ozone reduction that can be achieved by controlling domestic anthropogenic emissions of air pollutants, and thus are crucial for assessing the effectiveness and potential of emission control measures. The large 9.5 ppbv mean differences reflect a strong interactional effect of domestic anthropogenic emissions with soil $\mathrm{NO}_{\mathrm{x}}$ emissions in the NCP that has not been studied before. Additional analyses on July 2016 and 2018 suggest that this effect is robust for other years with small interannual variabilities in the magnitude (Supplementary Fig. 5).

We find a similar strong effect of soil $\mathrm{NO}_{\mathrm{x}}$ emissions on anthropogenic ozone in the NCP using the WRF-Chem regional air quality model, suggesting the feature is robust among air 

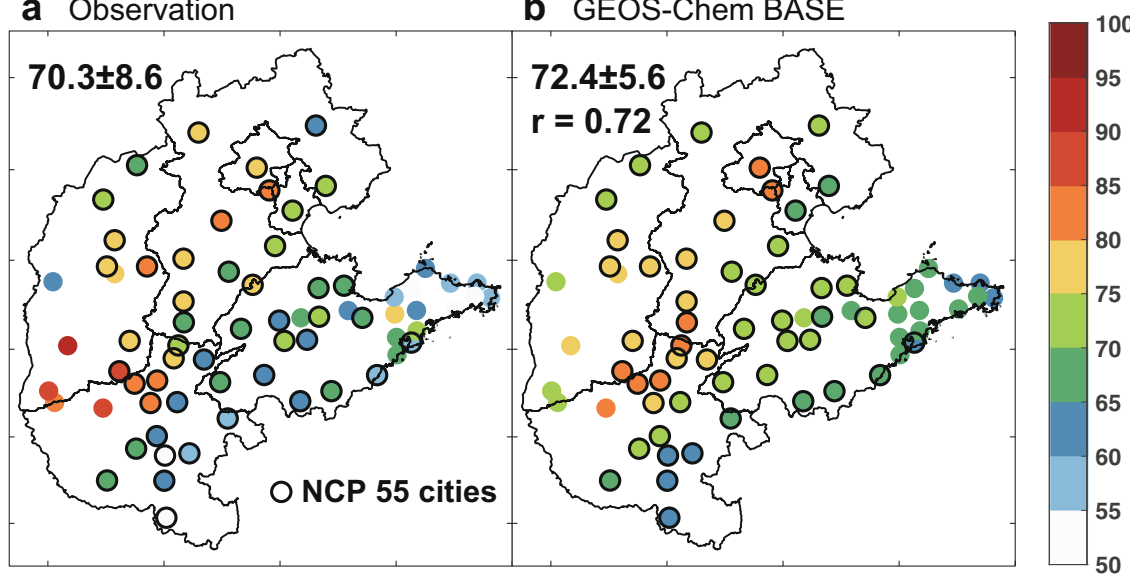

Anthropogenic ozone

C contribution with soil emissions

d Anthropogenic ozone

[ppbv]

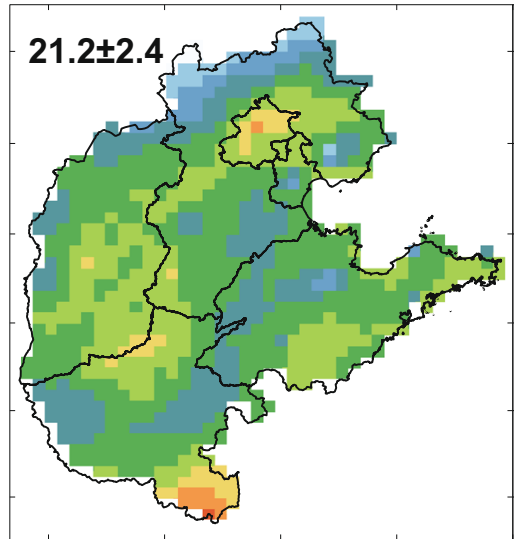

contribution without soil emissions
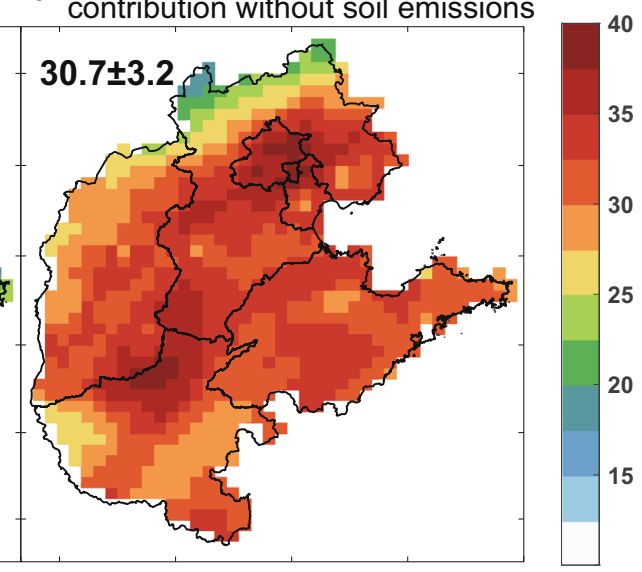

[ppbv]

Fig. 2 Soil $\mathbf{N O}_{\mathbf{x}}$ emission influences on surface ozone levels and estimated anthropogenic ozone contribution. Panels a and $\mathbf{b}$ show the spatial distribution of $\mathbf{a}$ observed and $\mathbf{b}$ simulated mean MDA8 ozone at urban sites over the NCP in July 2017. Mean values \pm standard deviation and their spatial correlation coefficients $(r)$ in the 55 NCP cities categorized as key cities for air pollution monitoring (marked with black circles) are shown in the inset. Panels $\mathbf{c}, \mathbf{d}$ show ozone contributions from domestic anthropogenic emissions, estimated as the simulated ozone difference with domestic anthropogenic sources turned on/off, in the presence/absence of soil $\mathrm{NO}_{x}$ emissions (Methods). The mean values \pm standard deviation over the NCP grids are shown in the inset.

quality models. We apply the same anthropogenic and soil $\mathrm{NO}_{\mathrm{x}}$ emissions in the WRF-Chem model (Methods) as those used in GEOS-Chem (Supplementary Fig. 6). The mean anthropogenic ozone enhancement in the NCP estimated by WRF-Chem is 40 (60) ppbv in the presence (absence) of soil $\mathrm{NO}_{\mathrm{x}}$ emissions (Supplementary Fig. 7). The WRF-Chem model estimates larger anthropogenic ozone enhancements than GEOS-Chem, likely caused by the different treatments of other background sources and chemical mechanisms. However, the two models agree on the $30 \%$ reduction of anthropogenic ozone estimates when soil $\mathrm{NO}_{\mathrm{x}}$ emissions are considered in the NCP.

The presence of soil $\mathrm{NO}_{\mathrm{x}}$ emissions appears to suppress the sensitivity of summertime ozone pollution to anthropogenic sources in the NCP. This effect is different from another natural $\mathrm{NO}_{\mathrm{x}}$ source from lightning that emits in the free troposphere and has a much smaller influence on anthropogenic ozone attribution at the surface (Supplementary Fig. 8). We further illustrate the effects by conducting a series of GEOS-Chem sensitivity simulations for July 2017 with Chinese domestic anthropogenic $\mathrm{NO}_{\mathrm{x}}$ emissions reduced by, respectively, 20\%, 40\%, 60\%, 80\%, and $100 \%$ with and without soil $\mathrm{NO}_{\mathrm{x}}$ sources (Methods; Supplementary Table 3 ). Figure 3 shows the evolution of the NCP July mean surface MDA8 ozone concentrations under the different anthropogenic emission reduction scenarios. As we gradually reduce anthropogenic $\mathrm{NO}_{\mathrm{x}}$ emissions, ozone concentrations would decrease at accelerating rates, suggesting increasing efficiency of $\mathrm{NO}_{\mathrm{x}}$ control measures. The suppressed sensitivity of ozone to anthropogenic $\mathrm{NO}_{\mathrm{x}}$ imposed by soil $\mathrm{NO}_{\mathrm{x}}$ emissions, as indicated by the difference between the ozone decrease rates with same anthropogenic $\mathrm{NO}_{\mathrm{x}}$ reduction, in the presence vs. absence of soil emissions, also become greater under larger emission reduction conditions.

We use the ratio of surface $\mathrm{H}_{2} \mathrm{O}_{2}$ to $\mathrm{HNO}_{3}$ concentrations (hereafter $\mathrm{H}_{2} \mathrm{O}_{2} / \mathrm{HNO}_{3}$ ) as an indicator of the ozone formation regime ${ }^{42,43}$. Although the threshold of $\mathrm{H}_{2} \mathrm{O}_{2} / \mathrm{HNO}_{3}$ for determining ozone formation regime varies regionally ${ }^{42}$, a higher $\mathrm{H}_{2} \mathrm{O}_{2} / \mathrm{HNO}_{3}$ value typically indicates ozone formation being more sensitive to $\mathrm{NO}_{\mathrm{x}}$ emissions. As seen in Fig. 3, the NCP mean $\mathrm{H}_{2} \mathrm{O}_{2} / \mathrm{HNO}_{3}$ ratio is only 0.2 under the base condition, indicating a $\mathrm{NO}_{\mathrm{x}}$-saturated or transitional ozone formation regime, consistent with previous observation-based or model-inferred estimates $26,27 . \mathrm{H}_{2} \mathrm{O}_{2} / \mathrm{HNO}_{3}$ values increase with decreasing anthropogenic $\mathrm{NO}_{\mathrm{x}}$ emissions, and become greater than 1 for scenarios with over $80 \% \mathrm{NO}_{\mathrm{x}}$ emission reductions. If soil $\mathrm{NO}_{\mathrm{x}}$ emissions were excluded, the ozone formation regime in the NCP would shift towards a more $\mathrm{NO}_{\mathrm{x}}$-sensitive condition at the same 


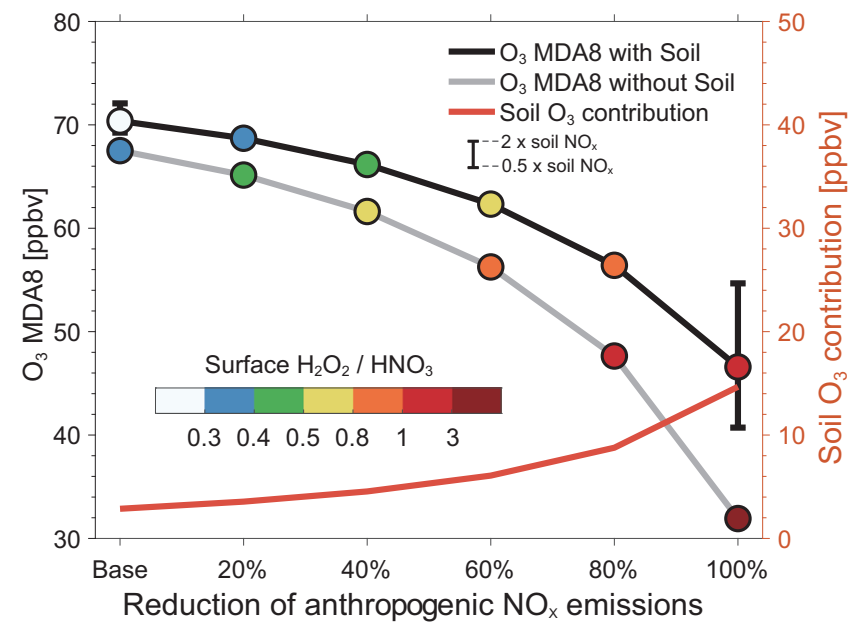

Fig. 3 The presence of soil $\mathrm{NO}_{x}$ emissions suppresses the sensitivity of ozone to anthropogenic $\mathbf{N O}_{\mathbf{x}}$ emissions. The GEOS-Chem simulated responses of MDA8 ozone in the NCP to the decline of anthropogenic $\mathrm{NO}_{x}$ emissions by 20, 40, 60, 80, and 100\% relative to July 2017 levels (left $y$-axis), in the presence (black line) and absence (gray line) of soil $\mathrm{NO}_{\mathrm{x}}$ emissions. The black bars represent the range of estimates with a factor of 2 uncertainty in soil $\mathrm{NO}_{x}$ emissions. The colored circles represent the mean surface $\mathrm{H}_{2} \mathrm{O}_{2} / \mathrm{HNO}_{3}$ ratios for each emission scenario. The red line (right $y$ axis) shows the corresponding ozone contribution from soil $\mathrm{NO}_{\mathrm{x}}$ emissions as can also be estimated from the difference between the black and gray lines.

anthropogenic $\mathrm{NO}_{\mathrm{x}}$ levels, and the shift would become much more distinct when anthropogenic $\mathrm{NO}_{\mathrm{x}}$ emissions are largely controlled and the soil becomes an increasingly important source of $\mathrm{NO}_{\mathrm{x}}$.

The interactional effect of soil and anthropogenic $\mathrm{NO}_{\mathrm{x}}$ emissions is also reflected by the suppression of ozone produced from soil $\mathrm{NO}_{\mathrm{x}}$ at high anthropogenic $\mathrm{NO}_{\mathrm{x}}$ levels. Ozone produced from soil emissions estimated from excluding soil $\mathrm{NO}_{\mathrm{x}}$ emissions in a sensitivity simulation (Methods) is only $2.9 \mathrm{ppbv}$ (1.7-4.6 ppbv considering a factor of 2 uncertainty in soil $\mathrm{NO}_{\mathrm{x}}$ emissions) in the NCP relative to the base simulation, and would increase to 15 ppbv (9-23 ppbv) when all domestic anthropogenic $\mathrm{NO}_{\mathrm{x}}$ emissions were turned off (Fig. 3). The more $\mathrm{NO}_{\mathrm{x}}$-sensitive chemical regime with reducing anthropogenic $\mathrm{NO}_{\mathrm{x}}$ emissions enhances the ozone production efficiency and thus leads to a greater ozone contribution from the soil. The enhanced soil ozone contribution offsets the expected ozone decrease driven by reduced anthropogenic $\mathrm{NO}_{\mathrm{x}}$ ozone contribution alone (gray line in Fig. 3), explaining the smaller total ozone reduction with vs. without soil $\mathrm{NO}_{\mathrm{x}}$ emissions.

We also find different influences of anthropogenic and soil $\mathrm{NO}_{\mathrm{x}}$ emissions on ozone formation in the NCP. Removing soil $\mathrm{NO}_{\mathrm{x}}$ emissions lower the July mean surface ozone levels by 2.9 ppbv, while reduction of a similar $\mathrm{NO}_{\mathrm{x}}$ amount from anthropogenic sources (i.e., $20 \%$ of anthropogenic sources as shown in Fig. 1) in the region would lead to $1.7 \mathrm{ppbv}$ lower ozone with a different spatial pattern (Supplementary Fig. 9) that can be largely attributed to the different spatial distribution of emissions. Reducing domestic anthropogenic $\mathrm{NO}_{\mathrm{x}}$ emissions by $20 \%$ would lead to ozone increases in cities, such as Beijing, Tianjin, and Shijiazhuang (Supplementary Fig. 9) as ozone formation in these urban areas is $\mathrm{NO}_{\mathrm{x}}$-saturated due to high anthropogenic $\mathrm{NO}_{\mathrm{x}}$ emissions. By contrast, removing soil $\mathrm{NO}_{\mathrm{x}}$ emissions would in general decrease ozone concentrations in the NCP, in particular over the high soil $\mathrm{NO}_{\mathrm{x}}$ emissions areas where ozone formation is more sensitive to $\mathrm{NO}_{\mathrm{x}}$. Ozone in these areas tends to have a longer lifetime than that in urban areas due to less titration (Supplementary Fig. 9), and can thus transport long distances and compensate ozone changes in the $\mathrm{NO}_{\mathrm{x}}$-saturated areas. This can be further supported by estimates of ozone production efficiency (OPE), defined as the number of ozone molecules produced per molecule of $\mathrm{NO}_{\mathrm{x}}$ emitted ${ }^{43}$. The NCP mean OPE in July contributed by soil $\mathrm{NO}_{\mathrm{x}}$ emissions is $28 \%$ higher than that contributed by $20 \%$ anthropogenic $\mathrm{NO}_{\mathrm{x}}$ emissions in the base simulation (36.4\% vs. $8.3 \%$ in Supplementary Fig. 9).

The implication of soil $\mathrm{NO}_{\mathrm{x}}$ emissions on ozone mitigation strategies. Our finding that soil $\mathrm{NO}_{\mathrm{x}}$ emissions strongly affect the sensitivity of ozone concentrations to anthropogenic sources in the NCP raises the need to assess its role in emission control strategies for improving ozone air quality. To address this issue, we apply GEOS-Chem model simulations to examine the responses of surface ozone in the NCP cities to reductions of anthropogenic $\mathrm{NO}_{\mathrm{x}}, \mathrm{VOCs}$, and $\mathrm{CO}$ emissions relative to the July 2017 level in the presence vs. absence of soil $\mathrm{NO}_{\mathrm{x}}$ emissions. We analyze three ozone exposure metrics relevant to air quality, human and vegetation health: MDA8, NDGT70, and AOT40 5,44 (Methods). Figure 4 shows the predicted percentage changes of these ozone metrics at the 55 NCP cities (Fig. 2a) under different emission reduction scenarios for July 2017. Compared to MDA8, the metrics of NDGT70 and AOT40 show greater sensitivity to declines in anthropogenic $\mathrm{NO}_{\mathrm{x}}$ emissions. It reflects high ozone concentrations as emphasized by the NDGT70 and AOT40 metrics are more sensitive to $\mathrm{NO}_{\mathrm{x}}$ emission reductions than ozone averages such as MDA8. Ozone formation in the NCP cities are typically $\mathrm{NO}_{\mathrm{x}}$-saturated (Supplementary Fig. 10), so that joint reduction of anthropogenic $\mathrm{NO}_{\mathrm{x}}, \mathrm{VOCs}$, and $\mathrm{CO}$ emissions can be more effective for ozone air quality improvement than controlling $\mathrm{NO}_{\mathrm{x}}$ emissions alone for small reduction intensities, but further ozone improvement will be determined by $\mathrm{NO}_{\mathrm{x}}$ reduction as ozone formation shifts eventually to be $\mathrm{NO}_{\mathrm{x}}$ limited (Fig. 4).

Distinct differences can be seen for the predicted ozone changes with vs. without soil $\mathrm{NO}_{\mathrm{x}}$ emissions considered (Fig. 4, Supplementary Table 4). Predicted ozone decreases associated with emission reductions would be much faster for all three metrics if there were no-soil $\mathrm{NO}_{\mathrm{x}}$ emissions. For $20 \%$ anthropogenic $\mathrm{NO}_{\mathrm{x}}$ emission reduction, predicted July mean ozone decreases in the NCP are $1.4 \%$ for MDA8, $2.3 \%$ for AOT40, and $4.6 \%$ for NDGT70 with soil $\mathrm{NO}_{\mathrm{x}}$ emissions included in the simulations. However, these values are $2.6 \%$ for MDA8, 5.5\% for AOT40, and $12 \%$ for NDGT70 without soil $\mathrm{NO}_{\mathrm{x}}$ emissions considered. In case of a greater emission reduction such as $60 \%$, predicted ozone decreases are $8.8 \%$ for MDA8, $18 \%$ of AOT40, and $34 \%$ for NDGT70 in the presence of soil NOx emissions vs. $15 \%$ for MDA $8,33 \%$ of AOT40, and $58 \%$ for NDGT70 in the absence of soil $\mathrm{NO}_{\mathrm{x}}$ emissions.

The 2018-2020 Chinese Clean Air Action plan called for a 9\% decrease for $\mathrm{NO}_{\mathrm{x}}$ emissions and $10 \%$ for VOC emissions relative to the 2017 level $^{25}$. These reductions are very likely not strong enough to reduce ozone levels at the NCP cities as seen from our model projection and from observations ${ }^{8,12}$, and more stringent emission control measures on $\mathrm{NO}_{\mathrm{x}}$ and VOCs are under design ${ }^{45}$. We show that large soil $\mathrm{NO}_{\mathrm{x}}$ emissions in the NCP present a previously overlooked challenge for future emission controls. To quantify it, we define the "soil $\mathrm{NO}_{\mathrm{x}}$ penalty" as the extra required anthropogenic emission reduction to achieve a target ozone level compared to the condition without soil $\mathrm{NO}_{\mathrm{x}}$ emissions. As shown in Fig. $4 \mathrm{c}, \mathrm{d}$, to achieve 5 ppbv reduction of MDA8 ozone on the basis of July 2017 conditions ( 70 ppbv), 41\% reduction of domestic anthropogenic $\mathrm{NO}_{\mathrm{x}}$ emissions as estimated from a 
a

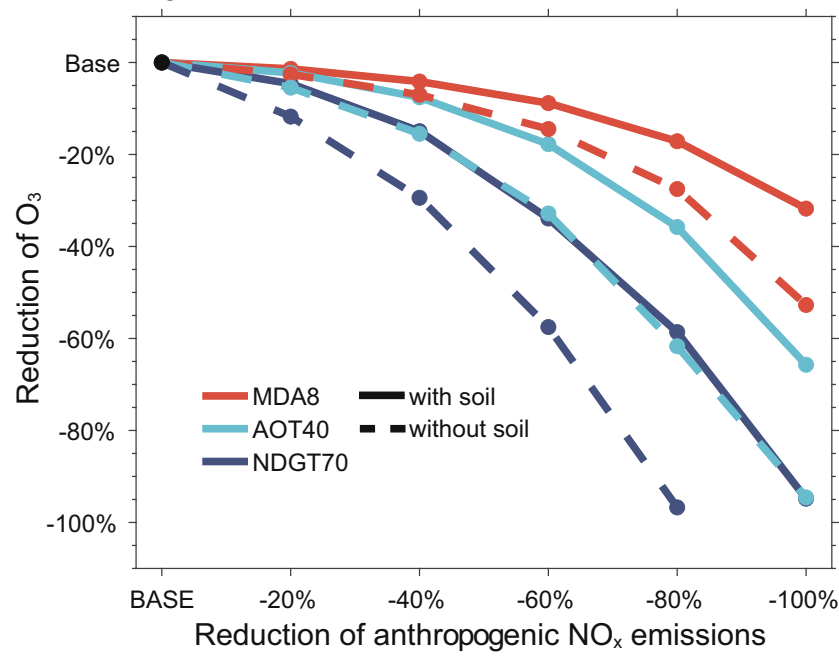

C

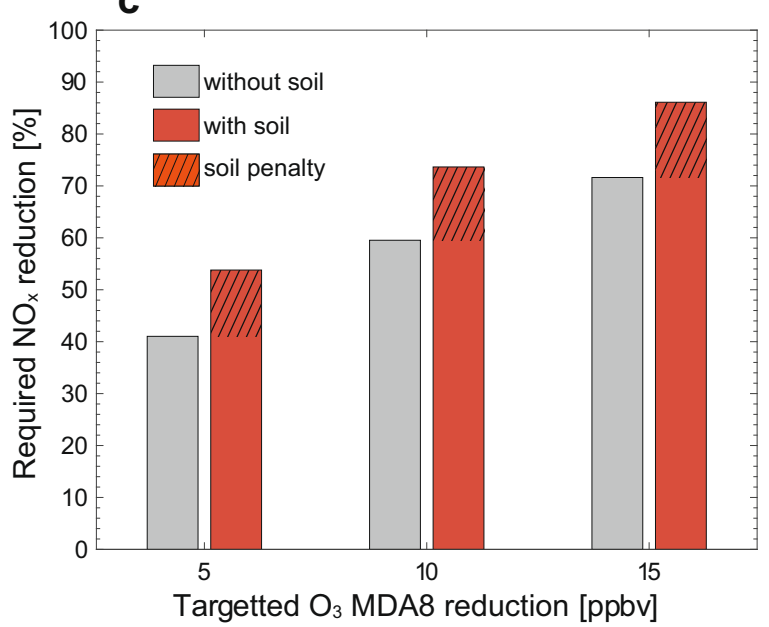

b

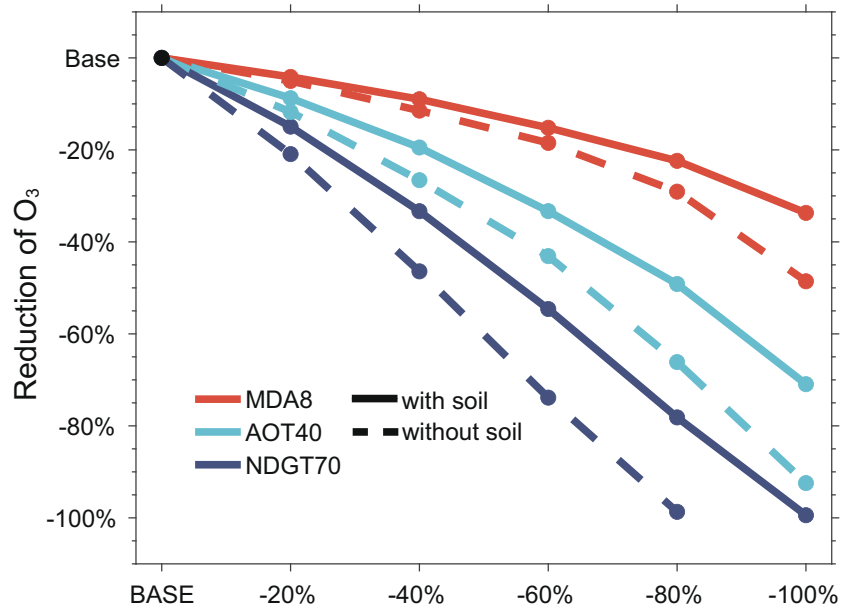

Reduction of anthropogenic $\mathrm{NO}_{x}, \mathrm{VOCs}$ and $\mathrm{CO}$ emissions

d

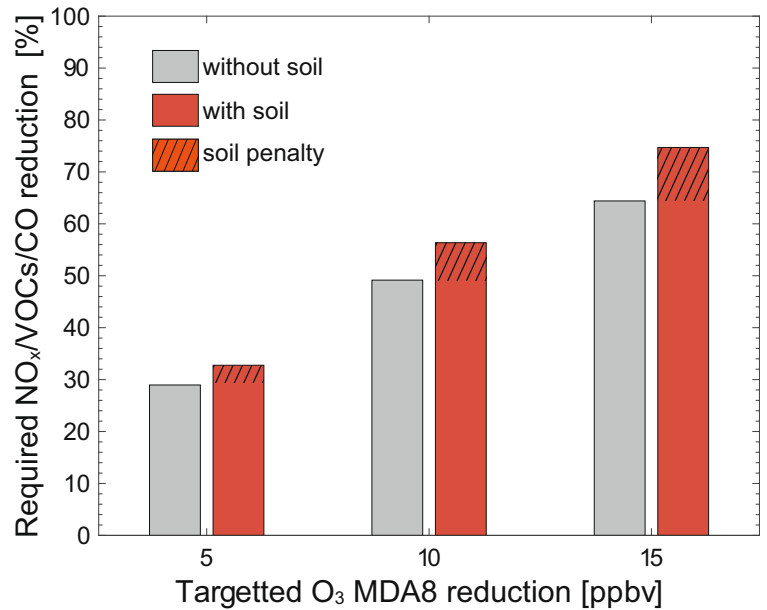

Fig. 4 The "soil $\mathbf{N O}_{\mathbf{x}}$ emission penalty" on anthropogenic ozone pollution regulation averaged in the $\mathbf{5 5} \mathbf{N C P}$ cities. Panels a and $\mathbf{b}$ show the responses of ozone metrics (MDA8, AOT40, and NDGT70, Methods) to the reductions of anthropogenic $\mathrm{NO}_{\mathrm{x}}$ emissions, and the joint reductions of anthropogenic $\mathrm{NO}_{\mathrm{x}}, \mathrm{VOCs}$, and CO emissions, respectively. Panels $\mathbf{c}$ and $\mathbf{d}$ show the required reduction of anthropogenic $\mathrm{NO}_{\mathrm{x}}$ emissions or joint reduction of anthropogenic $\mathrm{NO}_{x}, \mathrm{VOCs}$, and $\mathrm{CO}$ emissions for different ozone control targets in the NCP cities, estimated from panels $\mathbf{a}$ and $\mathbf{b}$ by a logarithmic fitting (Supplementary Table 5), both in the presence (gray) and absence (red) of soil $\mathrm{NO}_{x}$ emissions. The difference between the red and gray bars thus illustrates the soil $\mathrm{NO}_{x}$ emission penalty, i.e., extra anthropogenic emission reduction imposed by the presence of high soil $\mathrm{NO}_{x}$ emissions.

logarithmic fitting function (Supplementary Table 5) would be required if there were no-soil $\mathrm{NO}_{\mathrm{x}}$ emissions (i.e., if models neglect soil $\mathrm{NO}_{\mathrm{x}}$ emissions), but additional $13 \%$ emission reduction is required if soil $\mathrm{NO}_{\mathrm{x}}$ emissions are accounted for. The soil $\mathrm{NO}_{\mathrm{x}}$ emission penalty increases to $15 \%$ for a more ambitious ozone reduction target of $15 \mathrm{ppbv}$. Jointly controlling anthropogenic $\mathrm{NO}_{\mathrm{x}}, \mathrm{VOCs}$, and $\mathrm{CO}$ emissions by the same ratios can reduce the soil $\mathrm{NO}_{\mathrm{x}}$ penalty to 3.8 and $10 \%$ for 5 and $15 \mathrm{ppbv}$ ozone reduction targets, respectively. It can be expected that ozone control strategy design based on predictions without considering soil $\mathrm{NO}_{\mathrm{x}}$ emissions would largely underestimate the emission control efforts required to achieve an ozone air quality target.

In summary, our analyses have revealed an underappreciated role of soil $\mathrm{NO}_{\mathrm{x}}$ emissions, largely caused by agricultural fertilizer applications, on ozone air quality in the NCP. Our model simulations indicate that although the presence of soil $\mathrm{NO}_{\mathrm{x}}$ emissions here may only enhance the mean ozone concentrations by 2.9 ppbv for July 2017, it significantly hampers surface ozone pollution regulation by suppressing the sensitivity of ozone to combustion induced anthropogenic $\mathrm{NO}_{\mathrm{x}}$ emissions. It leads to additional $13-15 \%$ emission reductions (or $3.8-10 \%$ if also controlling VOCs and $\mathrm{CO}$ ) required to achieve ozone pollution reductions of 5-15 ppbv in the NCP cities. As combustion induced anthropogenic $\mathrm{NO}_{\mathrm{x}}$ emissions are being gradually reduced, such soil $\mathrm{NO}_{\mathrm{x}}$ emissions penalties would become increasingly prominent, and thus shall be accounted for in emission control strategies. We call for more direct measurements of soil $\mathrm{NO}_{\mathrm{x}}$ to better constrain its emissions in this region. The soil is also an important source of nitrous acid (HONO) ${ }^{46,47}$, another reactive nitrogen species contributing to ozone formation, and can have an even greater role than reported here in ozone air quality that needs to be assessed in future studies. The soil $\mathrm{NO}_{\mathrm{x}}$ effects on ozone air quality as revealed in this study can also be important in the Indo-Gangetic Plain, another region with high emissions of both anthropogenic and soil $\mathrm{NO}_{\mathrm{x}}$ (Supplementary Fig. 2). Management of the soil $\mathrm{NO}_{\mathrm{x}}$ emissions by improving the efficiency of nitrogen fertilizer application may have co-benefits on air quality, human health, food security, climate mitigation, and biodiversity conservation, helping solving the global nitrogen challenge ${ }^{48}$. 


\section{Methods}

Surface ozone observations over China. Surface ozone observations over China in July 2017 were obtained from the China National Environmental Monitoring Center (CNEMC) network (http://106.37.208.233:20035/). The CNEMC network reports hourly surface ozone concentrations at over 1500 sites covering more than 450 cities. Ozone measurements were reported in units of $\mu \mathrm{g} \mathrm{m}^{-3}$ at the standard atmospheric condition $(273.15 \mathrm{~K}, 1 \mathrm{~atm})$ and were converted to volume mixing ratios (ppb) in this study. We applied data quality control measures to remove unreliable data following our previous study ${ }^{5}$.

Ozone metrics relevant to air quality, human health, and vegetation exposure. We analyzed three ozone metrics (MDA8, NDGT70, and AOT40) characterizing ozone pollution and its impacts on human health and vegetation, following the Tropospheric Ozone Assessment Report (TOAR) ${ }^{44}$. The daily $8 \mathrm{~h}$ average maximum ozone (MDA8) is the standard metric used for ozone air quality regulation in China, and is widely used in cohort studies examining the responses of human health to ozone exposure ${ }^{2,49}$. The number of days with MDA8 $>70 \mathrm{ppb}$ (NDGT70) estimates the frequency of extreme ozone pollution episodes and acute health impact to ozone exposure ${ }^{44}$. The cumulative daytime hourly ozone concentrations of $>40 \mathrm{ppb}$ (AOT40) estimates ozone damages to vegetation.

Satellite observations of tropospheric $\mathrm{NO}_{2}$ column. We used observations of tropospheric $\mathrm{NO}_{2}$ column in July 2017 retrieved from the Ozone Monitoring Instrument (OMI). OMI is on board the NASA Earth Observing System (EOS) Aura satellite with an ascending equator crossing time at 13:45 local time (LT). It measures backscattered solar radiation in the ultraviolet and visible wavelength range of $270-504 \mathrm{~nm}^{50}$, and has a near-daily global coverage at a swath width of $2600 \mathrm{~km}$ and a pixel resolution of $13 \times 24 \mathrm{~km}^{2}$ at nadir view ${ }^{45}$. The OMI $\mathrm{NO}_{2}$ observations have been extensively applied to monitor $\mathrm{NO}_{2}$ air pollution and to interpret $\mathrm{NO}_{\mathrm{x}}$ emissions over China ${ }^{24,26,36,51}$

We obtained OMI tropospheric $\mathrm{NO}_{2}$ columns from three retrievals: the Peking University POMINO level 2 product version $2^{52,53}$ (https://www.amazon.com/ clouddrive/share/4tTaCCGYblD17KpJjh4PNnsGOetqwFffyPEzQChoaKz), the Dutch OMI $\mathrm{NO}_{2}$ level 2 product (DOMINO) version $2.0^{54}$ (https://www.temis.nl/ airpollution/no2.php), and the European Quality Assurance for Essential Climate Variables (QA4ECV) project's $\mathrm{NO}_{2}$ ECV precursor level 1.1 product ${ }^{55}$ (https:// www.temis.nl/airpollution/no2.php). We excluded pixels with snow-covered surfaces, row anomaly, or cloud fractions higher than $30 \%^{36}$. For comparison with the different observation products, GEOS-Chem simulated $\mathrm{NO}_{2}$ mixing ratios at 13-14 LT were sampled along the satellite tracks and smoothed by the corresponding averaging kernels.

Soil $\mathrm{NO}_{\mathrm{x}}$ emissions in China estimated by the Berkeley-Dalhousie Soil $\mathrm{NO}_{\mathrm{x}}$ Parameterization (BDSNP) and from the literature. The soil $\mathrm{NO}_{\mathrm{x}}$ emissions were estimated using the BDSNP ${ }^{37}$ implemented in GEOS-Chem. Meteorological variables used in the BDSNP scheme are obtained from the GEOS-FP assimilated meteorological data, available hourly at a horizontal resolution of $0.25^{\circ}$ (latitude) $\times$ $0.3125^{\circ}$ (longitude). The soil $\mathrm{NO}_{\mathrm{x}}$ emissions were calculated at each model grid and each hour. Here we briefly summarized the key features in the BDSNP parameterization, and more information could be found in the Supplement and from Hudman et al. $(2012)^{37}$.

The BDSNP parameterizes global soil $\mathrm{NO}_{\mathrm{x}}$ emissions $\left(E m i s_{\text {soil }}\right)$ as a function of available soil nitrogen content, climate, and edaphic conditions following:

$$
E m i s_{\text {soil }}=A_{\text {biome }}^{\prime}\left(N_{\text {avail }}\right) \times f(T) \times g(\theta) \times P\left(l_{\text {dry }}\right)
$$

where $N_{\text {avail }}$ represents available soil nitrogen mass, $A_{\text {biome }}^{\prime}$ denotes the biomedependent emission factors, $f(T)$ and $g(\theta)$ are the temperature and soil moisture dependences, and $P\left(l_{\mathrm{dry}}\right)$ describes the pulsed soil emissions from wetting of dry soils ${ }^{37}$. The soil temperature and moisture term $f(T) \times g(\theta)$ is given as:

$$
f(T) \times g(\theta)=e^{0.103 T} \times a \theta e^{-b \theta^{2}}
$$

where $T\left(0 \leq T \leq 30^{\circ}\right)$ is the soil temperature and $\theta(0 \leq \theta \leq 1)$ is the water-filled pore space. The Poisson function $g(\theta)$ describes the dependence on soil moisture. $\theta$ is defined as the ratio of the volumetric soil moisture content to the porosity. It is available hourly from the GEOS-FP meteorological fields for the top $2 \mathrm{~cm}$ of soil, where the majority of the soil $\mathrm{NO}_{\mathrm{x}}$ release. The values of $a$ and $b$ are chosen such that $g(\theta)$ maximizes when $\theta=0.2$ for arid soils and $\theta=0.3$ elsewhere according to laboratory and field measurements ${ }^{37}$.

The pulsing term $P\left(l_{\mathrm{dry}}\right)$ describes the pulsing of soil $\mathrm{NO}_{\mathrm{x}}$ emissions from a reactivation of water-stressed bacteria when very dry soil is wetted due to irrigation and/or rainfalls. It follows Yan et al. (2005) 56,57 and is given as:

$$
P\left(l_{\text {dry }}\right)=\left[13.01 \ln \left(l_{\text {dry }}\right)-53.6\right] \times e^{-c t}
$$

where $l_{\text {dry }}$ is the length of the antecedent dry period in hours, $c$ is a constant rate denoting the rise/fall time of the pulse, and $t$ is the model emission time step.

The BDSNP considers available soil nitrogen content $\left(N_{\text {avail }}\right)$ from the natural pool, fertilizer application, and nitrogen deposition. Fertilizer applications are obtained from the global gridded chemical fertilizer and manure application inventory at $0.5^{\circ} \times 0.5^{\circ 56,57}$, in which the chemical fertilizers were spatially disaggregated from the International Fertilizer Association (IFA) national totals for year 2000 conditions, and the manure fertilizer were obtained from the Food and Agriculture Organization of the United Nations (FAO) Gridded Livestock of the World (GLW) project. We find that the Chinese chemical fertilizer application (straight $\mathrm{N}$ application) from IFA as used in this study gives $19.6 \mathrm{Tg} \mathrm{N} \mathrm{a}^{-1}$ for 2000, comparable to the estimate of $22.2 \mathrm{Tg} \mathrm{N} \mathrm{a}^{-1}$ for 2017 from the China Statistical Yearbook (http://www.stats.gov.cn/tjsj/ndsj/). The uncertainties in the fertilizer input can be considered in our sensitivity simulations with different soil $\mathrm{NO}_{\mathrm{x}}$ scenarios. The annual fertilizer applications are then distributed over the satellite-derived growing season at each grid. The $N_{\text {avail }}$ from dry and wet nitrogen deposition is available from GEOS-Chem for each time step and is thus coupled to the model chemistry and deposition of reactive nitrogen compounds.

BDSNP estimated the multi-year mean global soil $\mathrm{NO}_{\mathrm{x}}$ emissions above canopy of $8.8-9.5 \mathrm{Tg} \mathrm{N} \mathrm{a}^{-1}$ using the MERRA2 $\left(0.5^{\circ} \times 0.625^{\circ}, 1980-2017\right)$ or GEOS-FP $\left(0.25^{\circ} \times\right.$ $0.3125^{\circ}, 2014-2017$ ) assimilated meteorological fields, within the range reported in previous bottom-up (3.3-10 $\left.\mathrm{Tg} \mathrm{N} \mathrm{a}^{-1}\right)$ and top-down $\left(7.9-16.8 \mathrm{Tg} \mathrm{N} \mathrm{a}^{-1}\right)$ estimates ${ }^{58}$ Here we summarized the estimated soil $\mathrm{NO}_{\mathrm{x}}$ emission over China at domestic or regional scales from previous studies in Supplementary Table 1, adapted from Huang et al. (2014) ${ }^{59}$. Three approaches were typically used, including (1) statistical or mechanistic models using meteorological parameters and edaphic conditions (e.g., soil temperature and moisture) to parameterize soil $\mathrm{NO}_{\mathrm{x}}$ emissions, based on field measured relationships between these variables and soil $\mathrm{NO}_{\mathrm{x}}$ emissions; (2) top-down estimates using satellite $\mathrm{NO}_{2}$ observations with the a priori inventory to constrain soil $\mathrm{NO}_{\mathrm{x}}$ emissions; and (3) upscaling the measurements from field campaigns to develop soil $\mathrm{NO}_{\mathrm{x}}$ emission inventories at regional or national scales. We found that the estimated Chinese annual soil $\mathrm{NO}_{\mathrm{x}}$ emissions above canopy from these studies showed a wide range of $0.48-1.38 \mathrm{Tg} \mathrm{N} \mathrm{a}^{-1}$. A recent study combining modeling and measurements from Huang et al. (2014) $)^{59}$ estimated the soil $\mathrm{NO}_{\mathrm{x}}$ emissions of 1.23 (95\% Confidence Limit: $0.59-2.13) \mathrm{Tg} \mathrm{N}$ year ${ }^{-1}$. Our estimates of $0.77 \mathrm{Tg} \mathrm{N} \mathrm{a}^{-1}$ using the BDSNP parameterization were in the middle of the range. BDSNP-estimated soil $\mathrm{NO}_{\mathrm{x}}$ fluxes were also comparable to field measurements across China (Fig. 1d, Supplementary Table 2). The wide range of soil $\mathrm{NO}_{\mathrm{x}}$ emission estimates reflected the differences in the methods and location/time focuses among these studies, and also the uncertainties in the BDSNP parameterization and/or in meteorological fields and fertilizer application input. We thus conducted sensitivity simulations by assuming a factor of 2 uncertainty (i.e., by applying $50 \%$ or $200 \%$ of the BDSNP estimates in the model as informed by Supplementary Table 1) in the BDSNP-estimated Chinese soil $\mathrm{NO}_{\mathrm{x}}$ emissions (Supplementary Table 3) and to quantify how the uncertainty in the soil $\mathrm{NO}_{\mathrm{x}}$ emission affects our analyses.

GEOS-Chem model simulation. We used the global chemical transport model GEOS-Chem v11-02rc (http://geos-chem.org) to interpret surface ozone pollution and its source attribution over China in July 2017. The model simulates a state-ofthe-art tropospheric $\mathrm{HO}_{\mathrm{x}}-\mathrm{NO}_{\mathrm{x}}$-VOCs-ozone-halogen-aerosol chemistry ${ }^{60,61}$, and is driven by the GEOS-FP assimilated meteorological data from the Goddard Earth Observing System (GEOS) of the NASA Global Modeling and Assimilation Office (GMAO). The temporal resolution is $1 \mathrm{~h}$ for surface meteorological variables (including variables used in the BDSNP scheme) and boundary layer height and $3 \mathrm{~h}$ for others. We applied a nested version of the model over East Asia $\left(70^{\circ}-140^{\circ} \mathrm{E}\right.$, $15^{\circ}-55^{\circ} \mathrm{N}$ ) at a horizontal resolution of $0.25^{\circ}$ (latitude) $\times 0.3125^{\circ}$ (longitude) Boundary conditions were archived from the global simulation at $2^{\circ} \times 2.5^{\circ}$ horizontal resolution. The model simulation covered July 2017 with a 6-month spinup run for initialization.

Our GEOS-Chem simulations applied the latest Chinese anthropogenic emission inventory for 2017 from the Multi-resolution Emission Inventory for China (MEIC; http: //www.meicmodel.org) ${ }^{6}$. The model also implemented a number of natural/biogenic emissions. Soil $\mathrm{NO}_{\mathrm{x}}$ emissions were calculated using the Berkeley-Dalhousie Soil $\mathrm{NO}_{\mathrm{x}}$ Parameterization (BDSNP) as introduced above Lightning $\mathrm{NO}_{\mathrm{x}}$ emissions were parameterized as a function of cloud-top height and spatially constrained by satellite observations of lightning flash rates ${ }^{62}$. Biogenic VOC emissions were estimated by the Model of Emissions of Gases and Aerosols from Nature (MEGAN version v2.1) algorithm ${ }^{63}$. Biomass burning emissions were from the Global Fire Emissions Database version 4 (GFED4) ${ }^{64}$. A more detailed model description and configuration can be found in Lu et al. (2019) ${ }^{13}$.

We designed a BASE simulation and a total of 33 sensitivity simulations to examine the role of anthropogenic and natural/biogenic (including soil and lightning) $\mathrm{NO}_{\mathrm{x}}$ emissions in ozone source attribution. The standard simulation (BASE) applied the anthropogenic and natural/biogenic emissions as described above. We then assessed the ozone source attribution using the standard "bruteforced" zero-out approach. Sensitivity simulations were conducted by excluding anthropogenic emissions of all primary emitted species over China (NoAnthro), excluding soil $\mathrm{NO}_{\mathrm{x}}$ emissions (NoSoil), excluding lighting $\mathrm{NO}_{\mathrm{x}}$ emission (NoLight) and excluding the combinations of these emissions (NoSoilLight, NoAnthroSoil, NoAnthroLight, and NoAnthroSoilLight) (Supplementary Table 3). Ozone differences between these simulations were used to estimate the ozone contributions from anthropogenic and individual natural/biogenic $\mathrm{NO}_{\mathrm{x}}$ sources, and the interactional (nonlinear) effects between the sources. For instance, ozone differences between the BASE and NoAnthro (BASE-NoAnthro), and between the NoSoil and NoAnthroSoil (NoSoil-NoAnthroSoil), estimated the domestic 
anthropogenic ozone enhancements in the presence/absence of soil $\mathrm{NO}_{\mathrm{x}}$ emissions, respectively. The comparison of BASE-NoAnthro and NoSoil-NoAnthroSoil illustrated how soil $\mathrm{NO}_{\mathrm{x}}$ emissions influenced anthropogenic ozone enhancements through the interactional effect with anthropogenic sources.

Six sensitivity simulations were conducted to examine the influences of uncertainties in the soil $\mathrm{NO}_{\mathrm{x}}$ emission on ozone formation and source attribution. This is done by applying $200 \%$ or $50 \%$ of the BDSNP-estimated Chinese soil $\mathrm{NO}_{\mathrm{x}}$ emissions in the model (i.e., a factor of 2 uncertainty to capture the range of soil $\mathrm{NO}_{\mathrm{x}}$ emission estimates from Supplementary Table 1) with three different anthropogenic emission scenarios (Supplementary Table 3).

We further examined the impacts of soil $\mathrm{NO}_{\mathrm{x}}$ emissions on the effectiveness of emission controls for ozone pollution mitigation. This was conducted by reducing the anthropogenic $\mathrm{NO}_{\mathrm{x}}$ emissions over China by $20,40,60,80$, and $100 \%$ relative to 2017 levels in BASE, both in the presence and absence of soil $\mathrm{NO}_{\mathrm{x}}$ emissions. We repeated these sets of simulations but with joint reductions of anthropogenic $\mathrm{NO}_{\mathrm{x}}$, NMVOCs, and CO emissions over China (Supplementary Table 3).

WRF-Chem model simulation. We applied the WRF-Chem model version 3.6.1 with online-coupled meteorology and chemistry ${ }^{65}$. The modeling domain of WRFChem covered eastern China with a $27 \mathrm{~km}$ horizontal resolution and 37 vertical layers. The initial and lateral boundary conditions of meteorology were provided by National Centers for Environmental Prediction (NCEP) FNL (Final) Operational Global Analysis data at $1^{\circ} \times 1^{\circ}$ horizontal resolution. The chemical conditions, physical and chemical parameterization schemes are summarized in Supplementary Table 6.

Our standard WRF-Chem simulation for July 2017 (WRF-Chem BASE) applied the same MEIC inventory for anthropogenic emissions over China as used in GEOS-Chem. It also implemented the MEGAN version 2.1 for biogenic VOCs emissions. MEGAN version 2.1 estimated soil $\mathrm{NO}_{\mathrm{x}}$ emissions as a function of temperature but the emissions were significantly underestimated as found in a number of previous studies $32,33,63$. Our WRF-Chem BASE simulation thus excluded soil $\mathrm{NO}_{\mathrm{x}}$ emissions calculated from MEGAN version 2.1. We then applied the monthly mean soil $\mathrm{NO}_{\mathrm{x}}$ emissions for July 2017 over China archived from the GEOS-Chem simulation as offline soil $\mathrm{NO}_{\mathrm{x}}$ emissions in the improved WRF-Chem simulation (WRF-Chem BASE + Soil). We further conducted WRF-Chem simulations with Chinese anthropogenic emissions excluded from the BASE and BASE + Soil scenarios, in order to evaluate the role of soil $\mathrm{NO}_{\mathrm{x}}$ emissions in ozone source attribution over China from the WRF-Chem model.

\section{Data availability}

Surface ozone measurements in China are available at http://106.37.208.233:20035. Satellite observations of tropospheric $\mathrm{NO}_{2}$ column are available at https://www.amazon. com/clouddrive/share/4tTaCCGYblD17KpJjh4PNnsGOetqwFffyPEzQChoaKz (the POMINO product), https://www.temis.nl/airpollution/no2.php (the DOMINO version 2.0 product), and https://www.temis.nl/airpollution/no2.php (the QA4ECV product). Observations of soil $\mathrm{NO}_{\mathrm{x}}$ emissions are available from the references as listed in Supplementary Table 1. Modeling outputs and data generated in this study have been deposited in https://doi.org/10.5281/zenodo.4740433 $3^{66}$ and is publically available.

\section{Code availability}

GEOS-Chem model codes, including the Berkeley-Dalhousie Soil $\mathrm{NO}_{\mathrm{x}}$ Parameterization (BDSNP), are available at https://github.com/geoschem/geos-chem/releases/tag/v11-02rc. WRF-Chem model codes are available at https://github.com/wrf-model/WRF/ releases/tag/V3.6.1.

Received: 9 November 2020; Accepted: 22 July 2021;

Published online: 18 August 2021

\section{References}

1. Monks, P. S. et al. Tropospheric ozone and its precursors from the urban to the global scale from air quality to short-lived climate forcer. Atmos. Chem. Phys. 15, 8889-8973 (2015).

2. Turner, M. C. et al. Long-term ozone exposure and mortality in a large prospective study. Am. J. Respir. Crit. Care Med. 193, 1134-1142 (2016).

3. Unger, N., Zheng, Y., Yue, X. \& Harper, K. L. Mitigation of ozone damage to the world's land ecosystems by source sector. Nat. Clim. Change 10, 134-137 (2020).

4. Chang, K.-L., Petropavlovskikh, I., Copper, O. R., Schultz, M. G. \& Wang, T. Regional trend analysis of surface ozone observations from monitoring networks in eastern North America. Eur. East Asia. Elem. Sci. Anth 5, 50 (2017).

5. Lu, X. et al. Severe surface ozone pollution in China: a global perspective Environ. Sci. Technol. Lett. 5, 487-494 (2018).
6. Zheng, B. et al. Trends in China's anthropogenic emissions since 2010 as the consequence of clean air actions. Atmos. Chem. Phys. 18, 14095-14111 (2018).

7. Zhang, Q. et al. Drivers of improved $\mathrm{PM}_{2.5}$ air quality in China from 2013 to 2017. Proc. Natl Acad. Sci. USA 116, 24463-24469 (2019).

8. $\mathrm{Lu}, \mathrm{X}$. et al. Rapid increases in warm-season surface ozone and resulting health impact in China Since 2013. Environ. Sci. Technol. Lett. 7, 240-247 (2020).

9. Fleming, Z. L. et al. Tropospheric Ozone Assessment Report: Present-day ozone distribution and trends relevant to human health. Elem. Sci. Anth 6, 12 (2018).

10. Gaudel, A. et al. Tropospheric Ozone Assessment Report: Present-day distribution and trends of tropospheric ozone relevant to climate and global atmospheric chemistry model evaluation. Elem. Sci. Anth 6, 39 (2018).

11. Li, K. et al. Anthropogenic drivers of 2013-2017 trends in summer surface ozone in China. Proc. Natl Acad. Sci. USA 116, 422-427 (2019).

12. Li, K. et al. A two-pollutant strategy for improving ozone and particulate air quality in China. Nat. Geosci. 12, 906-910 (2019).

13. Lu, X. et al. Exploring 2016-2017 surface ozone pollution over China: source contributions and meteorological influences. Atmos. Chem. Phys. 19, 8339-8361 (2019).

14. Li, K. et al. Increases in surface ozone pollution in China from 2013 to 2019 : anthropogenic and meteorological influences. Atmos. Chem. Phys. 20, $11423-11433$ (2020).

15. Liu, Y. \& Wang, T. Worsening urban ozone pollution in China from 2013 to 2017-Part 1: The complex and varying roles of meteorology. Atmos. Chem. Phys. 20, 6305-6321 (2020).

16. Le, T. et al. Unexpected air pollution with marked emission reductions during the COVID-19 outbreak in China. Science 369, 702-706 (2020).

17. Shi, Z. et al. Abrupt but smaller than expected changes in surface air quality attributable to COVID-19 lockdowns. Sci. Adv. 7(3), eabd6696 (2021).

18. Li, K. et al. Ozone pollution in the North China Plain spreading into the latewinter haze season. Proc. Natl Acad. Sci. USA 118, e2015797118 (2021).

19. Li, M. et al. MIX: a mosaic Asian anthropogenic emission inventory under the international collaboration framework of the MICS-Asia and HTAP. Atmos. Chem. Phys. 17, 935-963 (2017).

20. Zhang, Y. et al. Emissions of nitrous oxide, nitrogen oxides and ammonia from a maize field in the North China Plain. Atmos. Environ. 45, 2956-2961 (2011).

21. Zhang, L. et al. Agricultural ammonia emissions in China: reconciling bottomup and top-down estimates. Atmos. Chem. Phys. 18, 339-355 (2018).

22. Zhao, Y. et al. Atmospheric nitrogen deposition to China: a model analysis on nitrogen budget and critical load exceedance. Atmos. Environ. 153, 32-40 (2017).

23. Wang, Y. et al. Seasonal variability of $\mathrm{NO}_{\mathrm{x}}$ emissions over east China constrained by satellite observations: Implications for combustion and microbial sources. J. Geophys. Res. 112, D06301 (2007).

24. Lin, J. T. Satellite constraint for emissions of nitrogen oxides from anthropogenic, lightning and soil sources over East China on a highresolution grid. Atmos. Chem. Phys. 12, 2881-2898 (2012).

25. Three-Year Action Plan on Defending the Blue Sky (in Chinese) (Chinese State Council, 2018); http://www.gov.cn/zhengce/content/2018-07/03/ content_5303158.htm.

26. Jin, X. \& Holloway, T. Spatial and temporal variability of ozone sensitivity over China observed from the Ozone Monitoring Instrument. J. Geophys. Res. 120, 7229-7246 (2015).

27. Wang, T. et al. Ozone pollution in China: a review of concentrations, meteorological influences, chemical precursors, and effects. Sci. Total Environ. 575, 1582-1596 (2017).

28. Li, Q. et al. "New" reactive nitrogen chemistry reshapes the relationship of ozone to its precursors. Environ. Sci. Technol. 52, 2810-2818 (2018).

29. Lyu, X. et al. Causes of a continuous summertime $\mathrm{O}_{3}$ pollution event in Jinan, a central city in the North China Plain. Atmos. Chem. Phys. 19, 3025-3042 (2019).

30. Hudman, R. C., Russell, A. R., Valin, L. C. \& Cohen, R. C. Interannual variability in soil nitric oxide emissions over the United States as viewed from space. Atmos. Chem. Phys. 10, 9943-9952 (2010).

31. Romer, P. S. et al. Effects of temperature-dependent $\mathrm{NO}_{\mathrm{x}}$ emissions on continental ozone production. Atmos. Chem. Phys. 18, 2601-2614 (2018).

32. Oikawa, P. Y. et al. Unusually high soil nitrogen oxide emissions influence air quality in a high-temperature agricultural region. Nat. Commun. 6, 8753 (2015).

33. Almaraz, M. et al. Agriculture is a major source of $\mathrm{NO}_{\mathrm{x}}$ pollution in California. Sci. Adv. 4, eaao3477 (2018).

34. Li, G. et al. Widespread and persistent ozone pollution in eastern China during the non-winter season of 2015: observations and source attributions. Atmos. Chem. Phys. 17, 2759-2774 (2017).

35. Gao, M. et al. Ozone pollution over China and India: seasonality and sources. Atmos. Chem. Phys. 20, 4399-4414 (2020). 
36. Shah, V. et al. Effect of changing $\mathrm{NO}_{\mathrm{x}}$ lifetime on the seasonality and longterm trends of satellite-observed tropospheric $\mathrm{NO}_{2}$ columns over China. Atmos. Chem. Phys. 20, 1483-1495 (2020).

37. Hudman, R. C. et al. Steps towards a mechanistic model of global soil nitric oxide emissions: implementation and space based-constraints. Atmos. Chem. Phys. 12, 7779-7795 (2012).

38. Vinken, G. C. M., Boersma, K. F., Maasakkers, J. D., Adon, M. \& Martin, R. V. Worldwide biogenic soil $\mathrm{NO}_{\mathrm{x}}$ emissions inferred from $\mathrm{OMI} \mathrm{NO}_{2}$ observations. Atmos. Chem. Phys. 14, 10363-10381 (2014).

39. Li, D., Wang, X., Sheng, G., Mo, J. \& Fu, J. Soil nitric oxide emissions after nitrogen and phosphorus additions in two subtropical humid forests. J. Geophys. Res. 113, D16301 (2008).

40. Zhou, F. et al. A new high-resolution $\mathrm{N}_{2} \mathrm{O}$ emission inventory for China in 2008. Environ. Sci. Technol. 48, 8538-8547 (2014).

41. Tian, H. et al. A comprehensive quantification of global nitrous oxide sources and sinks. Nature 586, 248-256 (2020).

42. Sillman, S. The use of $\mathrm{NO}_{\mathrm{y}}, \mathrm{H}_{2} \mathrm{O}_{2}$, and $\mathrm{HNO}_{3}$ as indicators for ozone-NOxhydrocarbon sensitivity in urban locations. J. Geophys. Res. 100, 14175 (1995).

43. Zhang, Y. et al. Tropospheric ozone change from 1980 to 2010 dominated by equatorward redistribution of emissions. Nat. Geosci. 9, 875-879 (2016).

44. Lefohn, A. S. et al. Tropospheric ozone assessment report: Global ozone metrics for climate change, human health, and crop/ecosystem research. Elem. Sci. Anth 6, 28 (2018).

45. Solutions for control of volatile organic compounds (VOCs) in 2020 (in Chinese) (Ministry of Ecology and Environment (MEE), 2020); http://www. mee.gov.cn/xxgk2018/xxgk/xxgk03/202006/t20200624_785827.html? from $=$ timeline

46. $\mathrm{Su}, \mathrm{H}$. et al. Soil nitrite as a source of atmospheric $\mathrm{HONO}$ and $\mathrm{OH}$ radicals. Science 333, 1616-1618 (2011).

47. Liu, Y. et al. A comprehensive model test of the HONO sources constrained to field measurements at rural North China plain. Environ. Sci. Technol. 53 3517-3525 (2019).

48. Houlton, B. Z. et al. A world of co-benefits: solving the global nitrogen challenge. Earths Future 7, 1-8 (2019).

49. Jerrett, M. et al. Long-term ozone exposure and mortality. N. Engl. J. Med. 360, 1085-1095 (2009).

50. Levelt, P. F. et al. The ozone monitoring instrument. IEEE Trans. Geosci. Remote Sens. 44, 1093-1101 (2006).

51. Qu, Z. et al. Monthly top-down NOx emissions for China (2005-2012): a hybrid inversion method and trend analysis. J. Geophys. Res. 122, 4600-4625 (2017).

52. Lin, J. T. et al. Influence of aerosols and surface reflectance on satellite $\mathrm{NO}_{2}$ retrieval: seasonal and spatial characteristics and implications for NOx emission constraints. Atmos. Chem. Phys. 15, 11217-11241 (2015).

53. Liu, M. et al. Improved aerosol correction for OMI tropospheric $\mathrm{NO}_{2}$ retrieval over East Asia: constraint from CALIOP aerosol vertical profile. Atmos. Meas. Tech. 12, 1-21 (2019).

54. Boersma, K. F. et al. An improved tropospheric $\mathrm{NO}_{2}$; column retrieval algorithm for the Ozone Monitoring Instrument. Atmos. Meas. Tech. 4 , 1905-1928 (2011).

55. Boersma, K. F. et al. Improving algorithms and uncertainty estimates for satellite $\mathrm{NO}_{2}$ retrievals: results from the quality assurance for the essential climate variables (QA4ECV) project. Atmos. Meas. Tech. 11, 6651-6678 (2018).

56. Yan, X., Ohara, T. \& Akimoto, H. Statistical modeling of global soil $\mathrm{NO}_{\mathrm{x}}$ emissions. Glob. Biogeochem. Cycles 19, GB3019 (2005).

57. Potter, P., Ramankutty, N., Bennett, E. M. \& Donner, S. D. Characterizing the spatial patterns of global fertilizer application and manure production. Earth Interact. 14, 1-22 (2010).

58. Weng, H. et al. Global high-resolution emissions of soil NOx, sea salt aerosols, and biogenic volatile organic compounds. Sci. Data 7, 148 (2020).

59. Huang, Y. \& Li, D. Soil nitric oxide emissions from terrestrial ecosystems in China: a synthesis of modeling and measurements. Sci. Rep. 4, 7406 (2014).

60. Park, R. J., Jacob, D. J., Field, B. D., Yantosca, R. M. \& Chin, M. Natural and transboundary pollution influences on sulfate-nitrate-ammonium aerosols in the United States: implications for policy. J. Geophys Res. Atmos. 109, D15204 (2004).
61. Mao, J. et al. Ozone and organic nitrates over the eastern United States: sensitivity to isoprene chemistry. J. Geophys. Res. 118, 11,256-11,268 (2013).

62. Murray, L. T., Jacob, D. J., Logan, J. A., Hudman, R. C. \& Koshak, W. J. Optimized regional and interannual variability of lightning in a global chemical transport model constrained by LIS/OTD satellite data. J. Geophys. Res. 117, D20307 (2012).

63. Guenther, A. B. et al. The Model of Emissions of Gases and Aerosols from Nature version 2.1 (MEGAN2.1): an extended and updated framework for modeling biogenic emissions. Geosci. Model Dev. 5, 1471-1492 (2012).

64. van der Werf, G. R. et al. Global fire emissions estimates during 1997-2016. Earth Syst. Sci. Data 9, 697-720 (2017)

65. Grell, G. A. et al. Fully coupled "online" chemistry within the WRF model. Atmos. Environ. 39, 6957-6975 (2005).

66. Lu, X., Ye, X. P. \& Zhang, L. Dataset for The underappreciated role of agricultural soil nitrogen oxides emissions in ozone pollution regulation in North China. Zenedo https://doi.org/10.5281/zenodo.4740433 (2021).

\section{Acknowledgements}

The work was supported by the National Key Research and Development Program of China (2017YFC0210102) and the National Natural Science Foundation of China (41922037 and 71961137011).

\section{Author contributions}

L.Z., Y.H. Zhang, and X.L. designed the study. X.L., X.P.Y. and M.Z. performed model simulations and conducted data analysis with the assistance from Y.H. Zhao, H.J.W., H.K., K.L. and M.G., B.Z. and Q.Z. provided the Chinese anthropogenic emissions inventories. J.T.L. provided the POMINO $\mathrm{NO}_{2}$ products. F.Z. provided the agricultural $\mathrm{N}_{2} \mathrm{O}$ emissions. D.W. provided the soil $\mathrm{NO}_{\mathrm{x}}$ flux measurements (Beijing, Shandong, and Hubei). X.L. and L.Z. wrote the paper with valuable inputs from all authors.

\section{Competing interests}

The authors declare no competing interests.

\section{Additional information}

Supplementary information The online version contains supplementary material available at https://doi.org/10.1038/s41467-021-25147-9.

Correspondence and requests for materials should be addressed to L.Z. or Y.Z.

Peer review information Nature Communications thanks Alexander Bouwman, Zoë Fleming, and other, anonymous, reviewers for their contributions to the peer review of this work.

Reprints and permission information is available at http://www.nature.com/reprints

Publisher's note Springer Nature remains neutral with regard to jurisdictional claims in published maps and institutional affiliations.

\footnotetext{
Open Access This article is licensed under a Creative Commons Attribution 4.0 International License, which permits use, sharing adaptation, distribution and reproduction in any medium or format, as long as you give appropriate credit to the original author(s) and the source, provide a link to the Creative Commons license, and indicate if changes were made. The images or other third party material in this article are included in the article's Creative Commons license, unless indicated otherwise in a credit line to the material. If material is not included in the article's Creative Commons license and your intended use is not permitted by statutory regulation or exceeds the permitted use, you will need to obtain permission directly from the copyright holder. To view a copy of this license, visit http://creativecommons.org/ licenses/by/4.0\%
}

(C) The Author(s) 2021 